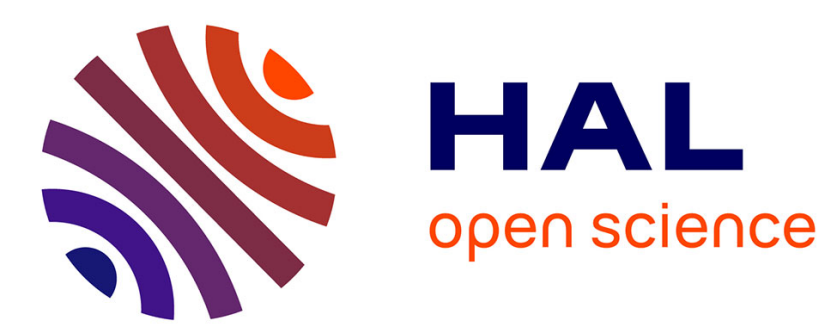

\title{
Can our understanding of epigenetics assist with primary prevention of congenital defects?
}

\author{
María-Luisa Martínez-Frías
}

\section{To cite this version:}

María-Luisa Martínez-Frías. Can our understanding of epigenetics assist with primary prevention of congenital defects?. Journal of Medical Genetics, 2010, 47 (2), pp.73. 10.1136/jmg.2009.070466 . hal-00552707

\section{HAL Id: hal-00552707 \\ https://hal.science/hal-00552707}

Submitted on 6 Jan 2011

HAL is a multi-disciplinary open access archive for the deposit and dissemination of scientific research documents, whether they are published or not. The documents may come from teaching and research institutions in France or abroad, or from public or private research centers.
L'archive ouverte pluridisciplinaire HAL, est destinée au dépôt et à la diffusion de documents scientifiques de niveau recherche, publiés ou non, émanant des établissements d'enseignement et de recherche français ou étrangers, des laboratoires publics ou privés. 


\title{
Review
}

\section{Can our understanding of epigenetics assist with primary prevention of congenital defects?}

\author{
María Luisa Martínez-Frías \\ Director of the Congenital Anomalies Research Centre (CIAC), Institute of Health \\ Carlos III (ISCIII), Madrid. \\ Researcher at the Biomedical Research on Rare Diseases Centre (CIBERER), ISCIII, \\ Madrid. \\ Professor, Department of Pharmacology, Faculty of Medicine, Universidad \\ Complutense de Madrid, Spain.
}

Address reprint requests to: Dr M.L. Martínez-Frías,

ECEMC,

Directora del CIAC,

Instituto de Salud Carlos III (ISCIII),

Sinesio Delgado 4-6, Pabellón 3, 1ª planta,

28029, Madrid, Spain.

Phone: 34918222424

FAX: 34913877800

E-mail: mlmartinez.frias@isciii.es

Keywords: Epigenetic, birth defects, development, primary prevention, environmental factors

\section{ACKNOWLEDGEMENTS:}

This work was in part supported by the "Fundación 1000 sobre Defectos Congénitos" and in part by the "Instituto de Salud Carlos III (ISCIII)". The "CIBER de ER" is an initiative of the ISCIII, Madrid. Spain. 


\begin{abstract}
Having identified teratogenic factors, primary prevention of congenital defects is possible by the implementation of specific measures in pregnant women or those planning pregnancy. Our current understanding of the epigenetic processes acting during reproductive events raises new possibilities to prevent both heritable and sporadic congenital anomalies. Cell differentiation during embryonic-foetal development involves different epigenetic processes which, if altered, may affect either somatic or germ cells. Epigenetic alterations can occur in somatic cells at different stages of life, from fecundation to adulthood, and when germ cells are affected, such changes can even be passed on to future generations.

This review summarizes the main epigenetic processes that influence gene expression and cell specification at different stages of development. The experimental and epidemiological evidence of environmental agents that cause epigenetic alterations is evaluated, as well as their effects in males and females. As a result, new avenues for primary prevention are proposed.
\end{abstract}

\title{
Words: 149
}




\section{Introduction}

It is clear that identifying the environmental factors that disrupt human embryonicfoetal development (teratogens) will facilitate the implementation of primary prevention strategies to avoid their adverse effects. Indeed, many epidemiological studies have analysed environmental risk factors that affect embryonic development, leading to the recommendation of a series of preventive measures for women prior to and during pregnancies [1-3]. At present, primary prevention of heritable conditions is only considered to be possible through assisted reproduction techniques (ART) and pre-implantation diagnosis. However, interventions such as prenatal diagnosis followed by termination of the affected pregnancies do not avoid the embryonic-foetal alterations and as such, they are considered by some as secondary prevention [1-3].

The spectacular amount of biological information generated by experimental and epidemiological studies in humans now permits that this can evaluated in a more integrated manner [4]. Therefore, our understanding of epigenetics and embryonic development is summarized here, to asses their implications for primary prevention of birth defects. The first part of this review focuses on the epigenetic processes that influence gene expression and cell specification, while the second sets out our current understanding of the initial stages of development from fecundation to gamete formation and maturation. Finally, we will summarize some of the evidence that environmental agents alter epigenetic processes during development in mammals and humans.

\section{Overview of epigenetic mechanisms}

The term epigenetics refers to the heritable changes in gene expression and cell phenotype in the absence of alterations to the DNA sequence. Hence, while the genome generally remains uniform in all the different cells of a complex organism, the epigenome controls the differential gene expression in most cell types, silencing or activating genes, and defining when and where they are expressed. In molecular terms, these events commonly involve chromatin modifications and cytosine methylation at $\mathrm{CpG}$ dinucleotides. Chromatin is principally made up of histones $(\mathrm{H} 2 \mathrm{~A}, \mathrm{H} 2 \mathrm{~B}, \mathrm{H} 3$ and $\mathrm{H} 4)$, proteins that are predominantly comprised of positively charged amino acids that bind to the negatively charged DNA. These histones coil DNA into nucleosomes, consisting of a core octamer of histones around which the DNA is wrapped. The amino-terminal tail of each core histone extends out from the nucleosome and it contains residues that can be epigenetically modified. Thus, the DNA/histone association is regulated by epigenetic mechanisms that inactivate gene transcription by condensing chromatin, activating it when the chromatin opens [5]. For 
example, the acetylation of histones neutralizes their positive charge and relaxes the chromatin structure, permitting gene transcription [6].

Several epigenetic mechanisms are known to regulate gene expression, such as: DNA methylation; chromatin remodelling; and complex histone modifications including acetylation for gene expression, phosphorylation for gene activation and repression (mainly through different families of methyl transferases, acetyl transferases and deacetylases) [6-9]. In addition, there are other less well understood protein modifications (e.g. ubiquitination, sumoylation), as well as other rapidly emerging epigenetic processes involving small noncoding RNAs, called microRNAs, that regulate gene function and expression during prenatal development and during germ-line formation in both sexes [10-13]. In addition, genomic imprinting is a type of epigenetic modification that leads to the selective expression of only one allele of autosomal genes or differential methylated regions (DMR), depending on their parental origin. That is, instead of the maternal and paternal alleles/DMR being expressed equally, their expression/repression depends on whether they are inherited from the mother or the father (Fig. 1). Hence, expression/repression of the same gene/DMR differs in the male and female gametes across generations [14]. In mammals, most of the known imprinted genes lie in clusters, or they are found in close proximity to one another, and the mechanisms responsible for the coordinated expression of these imprinted genes are now beginning to be understood [15-16].

Due to its inherent stability, DNA methylation is one of the most generalized epigenetic mechanisms in mammals and it represents a means to silence gene expression [17]. Unlike histone acetylation -which is a relatively dynamic modification- the methylation of $\mathrm{CpG}$ dinucleotide results in a stable yet potentially reversible in gene expression. Methylation occurs in the one-carbon cycle, where a methyl group from the S-adenosylmethionine (SAM) is covalently added to the carbon 5' of the DNA cytosine ring (CpG dinucleotide). This process is highly dependent on the levels of folate and it is catalysed by several DNA methyltransferases (DNMTs) [17-18], particularly: DNMT1, which maintains methylation patterns throughout DNA replication in the mouse and human genome; DNMT2, which appears to be involved in embryonic stem cells; DNMT3A and DNMT3B that participate in de novo methylation at $\mathrm{CpG}$ sites. In addition, DNMT3A appears to participate in germ cell imprinting through an interaction with another DNMT3 (DNMT3L), which is essential for genomic imprinting [19-21]. The protein groups that are involved in epigenetic modifications are closely coordinated and they form multiprotein complexes [22]. There are three types of DNA methylation/demethylation: de novo methylation, and passive or active demethylation. While passive demethylation is due to the failure to maintain methylation during DNA replication, such that the newly replicated strand is not methylated [23-24], the mechanisms underlying active demethylation are poorly understood in mammals. However, recent studies [25-26] suggested that this DNA demethylation is initiated by the same 
enzymes that establish the methylation marks in parental imprinting (DNMT3A and DNMT3B), although other possibilities have also been evaluated [27].

The methylation of the genome is not random in mammals and since it is tissuespecific, it is also responsible for different types of cells differing in their epigenetic stability. It was considered that DNA methylation patterns established during prenatal development may remain stable throughout life. However, we now know that far from being permanent, epigenetic modifications undergo important changes at particular stages of development. Moreover, it has been postulated that DNA-demethylase helps maintain the DNA methylation equilibrium in post-mitotic cells and that the DNA methylation machinery remains active throughout life [28]. Indeed, there is even evidence suggesting that at least some types of DNA methylation might change later in postnatal life [29-30].

Since some epigenetic processes active during embryonic and foetal development are conserved between mice and humans [28], our understanding of these processes in human development is growing dramatically.

\section{Epigenetic processes during fecundation and during embryonic and foetal development, or gamete formation}

At fecundation, the two parental gametes and genomes differ in their morphological asymmetry and in several other aspects (Fig. 2):

a) The paternal gamete is already haploid, while the maternal one is arrested at metaphase II containing a single set of chromosomes with double the DNA content.

b) The paternal genome is highly condensed by substituting the histones with protamines (which fold the DNA without forming nucleosomes). By contrast, the maternal chromatin is formed by nucleosomes.

c) Whereas the paternal gamete is mainly restricted to its DNA contain, the maternal one has duplicated most of its cytoplasm structures. It includes an important amount of maternally inherited transcription factors that are acquired during oocyte maturation (about 14,000 proteins from different families) [31]. These factors are fundamental to regulate the transition of the paternal and maternal pronuclei to the zygote. Among these factors are those that are necessary for histone modification and reprogramming of the paternal genome, as well as those needed to acquire pluripotency and for DNA synthesis during the first zygote divisions [32].

d) When the parental genomes come together in the cytoplasm of the oocyte, both are methylated including the maternal and paternal imprinted areas. Consequently, the zygotic genome needs to restore totipotency by undergoing epigenetic reprogramming.

e) The reprogramming of the highly condensed paternal genome replaces the protamines with histones, and rapidly initiates extensive genomewide demethylation. By contrast, the maternal genome needs to remain methylated until it finishes the second (asymmetric) meiotic division, forming the pronucleus and the second polar body (PB-II) that 
mainly contains DNA. Subsequently, the maternal genome will undergo passive DNA demethylation during the first zygote cleavages.

The importance of epigenetic mechanisms in critical processes during the initial stages of mammalian development is becoming ever more evident [33-46]. Moreover, two major phases of transcriptional activity have been identified in the transition from maternal zygotic control: a) from fecundation to the late 2-cell embryo; and b) the subsequent phases up to the blastocyst stage [33-35]. From studies in mice we know that the PB-II forms at the moment of fecundation (Fig. 3A) and that it remains tethered to the egg at the site where the $2^{\text {nd }}$ meiotic division occurred, considered to be the animal pole (lying opposite to the vegetal pole) [36-37]. The position of PB-II also determines the zygote's plane of polarity and the animal-vegetal axis that persists in the zygote [38-40], along which the first cleavage occurs by a meridian division to generate the first two blastomeres (about 30 hours after human fecundation: Fig. 3B,1,2). This meridian division is favoured by the molecules anchored in the cortical cytoplasm near the PB-II, which form an organizing centre that captures microtubules that extend from the poles of the zygote's first mitotic division spindle (Fig. 3B,1) [36-37]. This first cleavage breaks the embryo's symmetry, generating blastomeres with different developmental characteristics that predict the blastocyst axis (Fig. 3B,2,3) [3840].

Although there are different opinions regarding how the two cell populations in the blastocyst are formed [36,38-43], a consensus exists that some blastomeres develop into the embryonic part of the blastocyst, while others form the mural trophectoderm and the superficial part of the ICM or polar trophectoderm [40-41]. Indeed, epigenetic mechanisms are implicated in the cell fate decisions made from the earliest embryonic stages, and cell position and epigenetic information both influence cell fate determination [43]. Through experimental methylation of histone $\mathrm{H} 3$, the methylation state of the first two cell lineages was shown to depend on the orientation of the first blastomeres with respect to the animalvegetal axis, which is meridian at the first division (2-cell stage) and equatorial at the second. In addition, blastomeres with methylated histone $\mathrm{H} 3$ almost exclusively contribute to the inner cell mass (ICM) rather than to the trophectoderm (which is highly demethylated) [43]. These observations further support the notion that epigenetic mechanisms are implicated in cell fate decisions from the earliest embryonic stages, and that they distinguish the first two cells of the embryo (Fig. 3B), influencing their fate [43].

Interestingly, at the 8-cell morula stage genetic and epigenetic modifications occur that appear to influence the subsequent allocation of the cells to the blastocyst. Indeed, the DNA methyl-transferase-1o (Dnmt1o) protein, synthesized during the maturation of the mouse oocyte, is translocated to the nucleus at the 8-cell morula stage, while it remains in the cytoplasm at all the other pre-implantation stages [44-45]. Thus, Dnmt1o is only observed in the nucleus of the 8-cell morula, where it works together with Dnmt1s, another Dnmt1 protein expressed in the nucleus of early embryos, to maintain methylation and to ensure the 
accurate inheritance of DNA methylation imprinting in the mouse embryo [44-45]. In addition, the 8-cell morula embryo undergoes the process of compaction, whereby each blastomere acquires an apical-basal polarity, through epigenetic modifications. The molecular basis for polarization in the mouse embryo resides in the positioning of some transcription factors, such as mRNA from the Cdx2 gene (Caudal type homeobox transcription factor 2) [46-47]. In the polarized blastomeres of the 8-cell morula, most of the $\mathrm{Cdx} 2$ transcripts are at the apical poles and very few are in the basal poles.

These characteristics of the 8-cell morula appear to influence the subsequent allocation of the cells in the blastocyst, determining the position of the ICM during cavitation [40, 48] (Fig. 3C,1). At the 16-32 cell stage, the cells of the morula undergo symmetric or asymmetric divisions depending on their previously established fates (Fig. 3C,2) [41, 48]. Accordingly, symmetric divisions generate two similar outer cells while asymmetric divisions generate an outer and an inner cell that differ in their polarization status. Indeed, when these cells undergo symmetric division, the mRNA from $\mathrm{Cdx} 2$ is equally distributed between the two new cells. Conversely, when they divide asymmetrically, most of the Cdx2 mRNA is located in the outer daughter cell and with a lesser contribution in the inner cells, evidence of a true asymmetric division. As a result, cell polarity affects the spatial distribution of $\mathrm{Cdx} 2$ transcripts and in turn, $\mathrm{Cdx} 2$ expression reciprocally reinforces cell polarity. Consequently, cells with more $\mathrm{Cdx} 2$ transcripts in the 8 -cell morula and that divide symmetrically will essentially contribute to the trophectoderm more than the cells with less Cdx2 transcripts, which will give rise to the ICM [46-47]. Cavitation commences at about the 32 cell stage, just before implantation, in the vicinity of the cells that have undergone more symmetric than asymmetric divisions [37, 41] (Fig. 3C,3). It is believed that cavitation is driven by these cell divisions, since the outer cells from these divisions adhere more strongly to their inner sisters than the two outer cells produced by symmetric division [37, 41].

During gastrulation the primitive ectoderm cells from the ICM form the epiblast cells, which then give rise to two different cell lineages: the embryonic cells, and the primordial germ cells (PGCs) that represent the sole source for the next generation. As in mice, the formation of mature human germ cells (both sexes) commences very early in embryonic development, at the end of the $2^{\text {nd }}$ to $3^{\text {rd }}$ week after fecundation in the caudal wall of the yolk sac, prior to their migration towards the primitive sex glands (developing gonad). Once the PGCs arrive at the primitive gonads (between the $4^{\text {th }}$ and $5^{\text {th }}$ weeks of human gestation), extensive epigenetic reprogramming commences by erasing the specific parental imprinting, since the new imprinting must be established in the gametes according to the sex of the embryo [49- 53] (Fig. 1). At this stage the PGCs are bipotential since they may develop into either testis or ovaries, irrespective of their chromosomal constitution. However, it was recently demonstrated that at the time the PGCs arrive at the primitive gonads in the male mouse, the Sry gene (which is essential for initiating Sertoli cell differentiation in mammals) acts during a narrow time window (only 6 hours). In this period it initiates and maintains the 
expression of the autosomal Sox9 gene, which is required for testis formation [54]. Without the appropriate activity of Sry, the PGCs could develop female gonads even if the chromosomal sex is male. Afterwards, the PGCs will start to differentiate into the mature gametes, although this process occurs at different moments in the female and male.

In a human female embryo, the PGCs will transform into oogonias through successive mitotic divisions that occur throughout the $2^{\text {nd }}$ month of gestation in humans. During the $3^{\text {rd }}$ month, genetic and epigenetic processes will help them acquire their germ cell characteristics. At this time, the oogonia begin to differentiate into primary oocytes by initiating a meiotic prophase. After the diplotene stage of the prophase, once cross-over has occurred, the process is arrested and a long resting period is initiated that lasts into postnatal life. At puberty, the growth and maturation of the oocytes involves the progress of meiosis, the methylation of maternal imprints and de novo methylation to acquire the characteristics of the primary oocyte. This requires hypertrophy since the PB-I only includes a small portion of the cytoplasm and consequently, the intracellular organelles in the oocyte are doubled (lysosomes, endoplasmic reticulum, Golgi complex, mitochondria and others). Additionally, all the transcription factors and other substances necessary for the zygote to function until the end of the pre-implantation period must be synthesised. Thus, the hallmarks of having successfully completed oogenesis are those needed to acquire the specific post-fecundation activity [55-57].

In human male embryos, unlike females, the differentiation of PGCs into spermatogonia does not commence during development. By the $2^{\text {nd }}$ month of gestation the PGC enter into mitotic arrest (prospermatogonia) and they remain unchanged in the developing gonads throughout foetal development. In postnatal life, at puberty, the male PGCs initiate a continuous process of mitotic multiplication that will persist throughout adult life, generating spermatogonia that undergo meiosis to form gametes. As soon as meiosis starts, genome-wide DNA methylation occurs prior to the pachytene phase of meiosis and paternal imprints are progressively acquired. The meiotic process terminates in the formation of four spermatids that will give rise to the mature spermatozoids [57-58] (Fig.2).

Conversely, somatic cells generally maintain their gene expression/repression throughout embryonic-foetal development because they are mitotically heritable [17]. However, we know that the patterns of DNA methylation are highly dynamic in post-mitotic tissues, and not only in cancer cells. This dynamism suggests that the methylation/demethylation equilibrium reflects the gene/environment interactions. Therefore, as the epigenome is responsible for multiple cell signalling events, it may be vulnerable to deregulation by environmental factors that produce teratogenic and adverse epigenetic effects, which could even be transmitted to subsequent generations (when they affect PGCs and gametes). In addition, such deregulation events may produce stages of susceptibility to develop different diseases during postnatal life [59-67], referred to as "the foetal basis for adult disease" [68]. This concept explains how environmental factors acting during prenatal 
development can affect cell plasticity and adult susceptibility to develop different types of diseases under certain conditions, such as type II diabetes, cancer and others [66-67].

\section{Evidence that epigenetic deregulation may be caused by environmental agents}

There has been a dramatic increase in the evidence that environmental agents interfere with epigenetic processes during prenatal development, as well as during gamete formation and maturation, provoking different effects. These processes can have implications for primary prevention.

Lessons from diethylstilbestrol (DES). DES is a synthetic oestrogen that was widely prescribed to pregnant women in the mid-1900s. This drug was then demonstrated to affect all the aforementioned cell types [69-73], increasing the risk of genital tract malformations in infants [70], clear cell adenocarcinoma in females at puberty [71] and of breast cancer after the age of 40 [72]. Moreover, some of the effects of DES were also observed in the granddaughters and grandsons (second generation) of exposed mothers [70, 73]. Currently we know that DES may induce such effects by altering normal hormonal signalling through different gene targets involved in cancer, and through the response of others genes to oestrogen exposure [69]. Indeed, DES affects HOX gene expression in prenatally exposed mice, as well as in human uterine and cervical tissues in culture [74]. The HOX genes are transcription factors that regulate cell differentiation during embryonic implantation, development, and in the reproductive tract [75-76]. HOXA10 and HOXA11 are necessary for uterine endometrial cell receptivity, and for implantation in mice and humans [75]. Indeed, an oestrogen responsible element (ERE) in human HOXA10 mediates differential ligandspecific oestrogen-responsive transcription and hence, the ligand specificity of the HOXA10 ERE represents a molecular epigenetic mechanism by which DES can influence development [76].

Other endocrine disruptors $(E D)$. The effects of DES stimulated further studies into ED and environmental chemicals. Studies in pregnant rats exposed to the endocrine disruptor vinclozolin (an anti-androgenic pesticide) and methoxychlor (a fungicide with mixed estrogenic and anti-androgenic activity), demonstrated epigenetic alterations and effects over at least four generations [77-78]. ED are also regarded as the cause of embryonic testicular alterations and increased apoptosis of sperm cells in adult testes. Similarly, there is evidence in humans of the effects on germ cells of chemicals such as pesticides, polycyclic aromatic hydrocarbons, organophosphates, metals and life-style (alcohol, tobacco) [79-81].

Inhibitors of histone deacetylases (HDACs). Epigenetic processes are also altered by factors that inhibit HDACs. Indeed, conventional HDAC inhibitors produce defects quite similar to those observed after prenatal exposure to Valproic acid (VPA) [82], a potent inhibitor of HDACs [83]. Studies in mice demonstrated that VPA and Trichostatin drugs induce hyperacetylation in embryos at the level of the caudal neural tube and somites. Therefore, the effects of these drugs are likely to be mediated through the inhibition of 
HDACs, which may represent the molecular starting point for their teratogenic effects [8183]. Moreover, VPA induces demethylation at $\mathrm{CpG}$ sites in endogenous genes, indicating that VPA induces both hyperacetylation and demethylation [84]. Recently, Topiramate (TPM), another anticonvulsant drug, was also shown to inhibit HDACs and to possibly produce teratogenic effects in humans [85-86]. Hence, it is tempting to speculate that these drugs (and probably other substances) silence/activate some genes in a similar way as mutations in the same gene, mimicking their phenotypes and producing "phenocopies".

Chemical agents that affect the epigenome as a whole. General alterations of genomic methylation (either hypomethylation or hypermethylation) have been observed in adult mice both in vivo and in vitro. For example, the cytotoxic agent 5-Aza-2'-deoxycytidine (5-Aza$\mathrm{CdR}$ ) is a strong inhibitor of DNA methylation and it stimulates the expression of some genes [87]. In humans, global hypomethylation in T cells occurs in systemic lupus erythematosus (SLE) [86], and some DNA binding proteins implicated in demethylation are more strongly expressed in T cells from patients with SLE [88]. Other drugs such as procainamide (antiarrhythmic) and hydralazine (anti-hypertensive) produce global hypomethylation in $\mathrm{T}$ cells by inhibiting DNA methylation, producing lupus like symptoms and providing evidence of how an environmental agent can induce a late onset disease [89]. Epigenetic modifications acquired during embryonic-foetal development also appear to increase the susceptibility to develop certain diseases later in life, such as cancer and type II diabetes [90]. In addition, DNA methylation in monozygotic twins also emerge later in life [91].

Nutritional deficiencies. These are among the most important environmental agents affecting the epigenome as a whole, as evident through the effects of starvation and severe nutritional alteration during pregnancy. Such effects were observed in individuals born to starving mothers during the Dutch famine [92-93]. Indeed, the problems identified in this population affected fertility and fecundity, obesity and the risk of disease in later life, and certain changes were transmitted to subsequent generations [93]. Additionally, epidemiological studies on women with other types of nutritional imbalances during gestation demonstrated an increased risk for birth defects and other reproductive problems [94].

Assisted reproduction technologies (ART). All the procedures used in ART have been implicated in congenital defects, including altered imprinting. ART have been related with an increased risk of infants having Beckwith-Wiedemann (BWS), Prader-Willi/Angelman and Silver-Russell syndromes, among other defects [95-97]. In a cohort study of discordant MZT for BWS, an imprinting defect was observed in KCNQ10T1 of a twin with BWS that was not present in the healthy co-twin [98]. Indeed, the failure to maintain the methylation imprinting centre 2 (DMR2), due to the abnormal expression of DNMT1, was postulated as an underlying cause of BWS [99]. Moreover, inactivation of Dnmt1s was shown to reduce the methylation in regions where methylation must be maintained after fecundation [97]. 


\section{Comments and conclusions}

The equilibrium between environmental alterations and genome function is the result of a network of DNA activities that show a high degree of plasticity to produce a wide range of specific responses to different types of environmental modifications. However, at the same time, DNA may be vulnerable to deregulation by environmental agents [59]. Taking all the aforementioned observations into consideration, it has become clear that epigenetic alterations can affect gene expression, producing different types of defects and diseases that may be transmitted to descendants, even over several generations.

These findings have important implications for the primary prevention of birth defects and for some long-term diseases, which cannot be ignored. First, because the biological processes and the effects of their alterations, have already been documented in some cases. Second, because the interventions to efficiently prevent such effects are easy, safe and cheap to implement. Indeed, we only need to spread the information that current preventive measures to prevent birth defects should be followed by both parents from three months before attempting to become pregnant, and they should be followed until the beginning of the second month of gestation by the father, and during the entire pregnancy by the mother. In this sense, to increase their efficacy it would be important to spread this information to the pre-pubescent and childbearing populations, irrespective of gender.

To conclude, our current understanding of epigenetic processes opens the door to promote more efficient primary prevention for a wide spectrum of birth defects and other heritable and sporadic diseases.

\section{Words: 3,997.}

The Corresponding Author has the right to Grant an exclusive licence on a worldwide basis to the BMJ Publishing Group Ltd to permit this article (if accepted) to be published in Journal of Medical Genetics and any other BMJPGL products and sublicences such use and exploit all subsidiary rights, as set out in our licence forms." 


\section{References}

1. Czeizel A. What proportion of congenital abnormalitites can be prevented? Brit Med Jour. 1993; 306:499-503.

2. Huddart SN, Bianchi A, Doig CM, Dickson AP. Preventing congenital abnormalities. Brit Med Jour, 1993; 306:857.

3. Saunders P. Preventing congenital abnormalities. Brit Med Jour. 1993;306: 857.

4. Martínez-Frías ML. Genetic drift. The balance of nature: reflections on the physics and mathematics structure of the living world and the human genome. Am J Med Genet A.2008; 146A:1781-1787..

5. Zamudio NM, Chong S, O'Bryan MK. Epigenetic regulation in male germ cells. Reproduction. 2008; 136:131-146.

6. Shahbazian MD, Grunstein M. Functions of site-specific histone acetylation and deacetylation. Annu Rev Biochem. 2007; 76:75-100.

7. Cheung P, Lau P. Epigenetic regulation by histone methylation and histone variants. Mol Endocrinol. 2005; 19:563-573.

8. Varga-Weisz PD, Becker PB-II. Regulation of higher-order chromatin structures by nucleosome-remodelling factors. Curr Opin Genet Dev. 2006;16:151-156.

9. Kouzarides T. Chromatin modifications and their function. Cell. 2007;128:693-705.

10. Filipowicz W, Bhattacharyya SN, Sonenberg N. Mechanisms of post-transcriptional regulation by microRNAs: are the answers in sight? Nat Rev Genet. 2008; 9:102-114.

11. Seila AC, Sharp PA. Small RNAs tell big stories in Whistler. Nat Cell Biol. 2008;10:630-633.

12. Hayashi K, Chuva de Sousa Lopes SM, Kaneda M, Tang F, Hajkova P, Lao K, O'Carroll D, Das PP, Tarakhovsky A, Miska EA, Surani MA. MicroRNA biogenesis is required for mouse primordial germ cell development and spermatogenesis. PLOS ONE. 2008;3:e1738.

13. Tam OH, Aravin AA, Stein P, Girard A, Murchison EP, Cheloufi S, Hodges E, Anger M, Sachidanandam R, Schultz RM, Hannon GJ. Pseudogene-derived small interfering RNAs regulate gene expression in mouse oocytes. Nature 2008;453:534-538.

14. Horsthemke B, Buiting K. Genomic imprinting and imprinting defects in humans. Adv Genet.2008;61:225-246.

15. Duncan EM, Muratore-Schroeder TL, Cook RG, Garcia BA, Shabanowitz J, Hunt DF, Allis CD. Cathepsin L proteolytically processes histone $\mathrm{H} 3$ during mouse embryonic stem cell differentiation. Cell. 2008;135:284-294.

16. Santos-Rosa H, Kirmizis A, Nelson C, Bartke T, Saksouk N, Cote J, Kouzarides T. Histone H3 tail clipping regulates gene expression. Nat Struct Mol Biol. 2009;16:17-22.

17. Bird A. DNA methylation patterns and epigenetic memory. Genes Dev. 2002;16:6-21.

18. Costello JF, Plass C. Methylation matters. J Med Genet.2001;38:285-303. 
19. Ooi SK, Qiu C, Bernstein E, Li K, Jia D, Yang Z, Erdjument-Bromage H, Tempst P, Lin SP, Allis CD, Cheng X, Bestor TH. DNMT3L connects unmethylated lysine 4 of histone H3 to de novo methylation of DNA. Nature. 2007;448:714-717.

20. Song F, Mahmood S, Ghosh S, Liang P, Smiraglia DJ, Nagase H, Held WA. Tissue specific differentially methylated regions (TDMR): Changes in DNA methylation during development. Genomics.2009; 93:130-913.

21. Brown SE, Suderman MJ, Hallett M, Szyf M. DNA demethylation induced by the methyl-CpG-binding domain protein MBD3. Gene. 2008;420:99-106.

22. Rountree MR, Bachman KE, Baylin SB. DNMT1 binds HDAC2 and a new corepressor, DMAP1, to form a complex at replication foci. Nat Genet. 2000;25:269-277.

23. Dean W, Santos F, Reik W. Epigenetic reprogramming in early mammalian development and following somatic nuclear transfer. Semin Cell Dev Biol 2003;14:93100.

24. Morgan HD, Santos F, Green K, Dean W, Reik W. Epigenetic reprogramming in mammals. Hum Mol Genet. 2005;1:R47-58.

25. Kangaspeska S, Stride B, Métivier R, Polycarpou-Schwarz M, Ibberson D, Carmouche RP, Benes V, Gannon F, Reid G. Transient cyclical methylation of promoter DNA. Nature. 2008;452:112-115.

26. Métivier R, Gallais R, Tiffoche C, Le Péron C, Jurkowska RZ, Carmouche RP, Ibberson D, Barath P, Demay F, Reid G, Benes V, Jeltsch A, Gannon F, Salbert G. Cyclical DNA methylation of a transcriptionally active promoter. Nature.2008;452:4550.

27. Ooi SK, Bestor TH. The colorful history of active DNA demethylation. Cell. 2008;133:1145-1148.

28. Szyf M, McGowan P, Meaney MJ. The social environment and the epigenome. Environ Mol Mutagen. 2008;49:46-60

29. Sasaki H, Matsui Y. Epigenetic events in mammalian germ-cell development: reprogramming and beyond. Nat Rev Genet. 2008;9:129-140.

30. Miller CA, Sweatt JD. Covalent modification of DNA regulates memory formation. Neuron. 2007;53:857-869. Erratum in: Neuron. 2008;59:1051.

31. Edwards RG. Genetics, epigenetics, and gene silencing in differentiating mammalian embryos. Reprod Biomed Online. 2006;13:732-753.

32. Bultman SJ, Gebuhr TC, Pan H, Svoboda P, Schultz RM, Magnuson T. Maternal BRG1 regulates zygotic genome activation in the mouse. Genes Dev. 2006;20:1744-1754

33. Torres-Padilla ME, Zernicka-Goetz M. Role of TIF1alpha as a modulator of embryonic transcription in the mouse zygote. J Cell Biol. 2006;174:329-338.

34. Wang QT, Piotrowska K, Ciemerych MA, Milenkovic L, Scott MP, Davis RW, Zernicka-Goetz M. A genome-wide study of gene activity reveals developmental signaling pathways in the preimplantation mouse embryo. Dev Cell. 2004;6:133-144. 
35. Niwa H, Toyooka Y, Shimosato D, Strumpf D, Takahashi K, Yagi R, Rossant J. Interaction between Oct $3 / 4$ and $\mathrm{Cdx} 2$ determines trophectoderm differentiation. Cell. 2005;123:917-929.

36. Gardner RL. The early blastocyst is bilaterally symmetrical and its axis of symmetry is aligned with the animal-vegetal axis of the zygote in the mouse. Development. 1997;124:289-301.

37. Zernicka-Goetz M. Cleavage pattern and emerging asymmetry of the mouse embryo. Nat Rev Mol Cell Biol.2005; 6:919-928.

38. Plusa B, Grabarek JB, Piotrowska K, Glover DM, Zernicka-Goetz M. Site of the previous meiotic division defines cleavage orientation in the mouse embryo. Nat Cell Biol.2002; 4:811-815. Erratum in: Nat Cell Biol.2002;4:912 .

39. Piotrowska K, Wianny F, Pedersen RA, Zernicka-Goetz M. Blastomeres arising from the first cleavage division have distinguishable fates in normal mouse development. Development. 2001;128:3739-3748.

40. Plusa B, Hadjantonakis AK, Gray D, Piotrowska-Nitsche K, Jedrusik A, Papaioannou VE, Glover DM, Zernicka-Goetz M. The first cleavage of the mouse zygote predicts the blastocyst axis. Nature.2005;434:391-395.

41. Zernicka-Goetz M. The first cell-fate decisions in the mouse embryo: destiny is a matter of both chance and choice. Curr Opin Genet Dev. 2006;16:406-412.

42. Gardner RL. The axis of polarity of the mouse blastocyst is specified before blastulation and independently of the zona pellucida. Hum Reprod. 2007;22:798-806.

43. Torres-Padilla ME, Parfitt DE, Kouzarides T, Zernicka-Goetz M. Histone arginine methylation regulates pluripotency in the early mouse embryo. Nature. 2007;445:214218.

44. Ratnam S, Mertineit C, Ding F, Howell CY, Clarke HJ, Bestor TH, Chaillet JR, Trasler JM. Dynamics of Dnmt1 methyltransferase expression and intracellular localization during oogenesis and preimplantation development. Dev Biol. 2002;245:304-314.

45. Cirio MC, Ratnam S, Ding F, Reinhart B, Navara C, Chaillet JR. Preimplantation expression of the somatic form of Dnmt1 suggests a role in the inheritance of genomic imprints. BMC Dev Biol. 2008;8:9.

46. Strumpf D, Mao CA, Yamanaka Y, Ralston A, Chawengsaksophak K, Beck F, Rossant J. $\mathrm{Cdx} 2$ is required for correct cell fate specification and differentiation of trophectoderm in the mouse blastocyst. J. Development. 2005;132:2093-2102.

47. Jedrusik A, Parfitt DE, Guo G, Skamagki M, Grabarek JB, Johnson MH, Robson P, Zernicka-Goetz M. Role of Cdx2 and cell polarity in cell allocation and specification of trophectoderm and inner cell mass in the mouse embryo. Genes Dev. 2008;22:26922706.

48. Bischoff M, Parfitt DE, Zernicka-Goetz M. Formation of the embryonic-abembryonic axis of the mouse blastocyst: relationships between orientation of early cleavage 
divisions and pattern of symmetric/asymmetric divisions. Development. 2008;135:953962.

49. Reik W, Dean W. DNA methylation and mammalian epigenetics. Electrophoresis. 2001;22:2838-2843.

50. Santos F, Hendrich B, Reik W, Dean W. Dynamic reprogramming of DNA nethylation in the early mouse embryo. Dev Biol. 2002;241:172-182.

51. Li E. Chromatin modification and epigenetic reprogramming in mammalian development. Nat Rev Genet. 2002;3:662-673.

52. Seki Y, Hayashi K, Itoh K, Mizugaki M, Saitou M, Matsui Y. Extensive and orderly reprogramming of genome-wide chromatin modifications associated with specification and early development of germ cells in mice. Dev Biol. 2005;278:440-458.

53. Seki Y, Yamaji M, Yabuta Y, Sano M, Shigeta M, Matsui Y, Saga Y, Tachibana M, Shinkai Y, Saitou M. Cellular dynamics associated with the genome-wide epigenetic reprogramming in migrating primordial germ cells in mice. Development. 2007;134:2627-2638.

54. Hiramatsu R, Matoba S, Kanai-Azuma M, Tsunekawa N, Katoh-Fukui Y, Kurohmaru M, Morohashi K, Wilhelm D, Koopman P, Kanai Y. A critical time window of Sry action in gonadal sex determination in mice. Development. 2009;136:129-138.

55. Bromfield J, Messamore W, Albertini DF. Epigenetic regulation during mammalian oogenesis. Reprod Fertil Dev. 2008;20:74-80.

56. Wassarman PM, Litscher ES. Mammalian fertilization: the egg's multifunctional zona pellucida. Int J Dev Biol. 2008;52:665-676.

57. Wassarman PM, Litscher ES. Mammalian fertilization is dependent on multiple membrane fusion events. Methods Mol Biol. 2008;475:99-113.

58. Zheng J, Xia X, Ding H, Yan A, Hu S, Gong X, Zong S, Zhang Y, Sheng HZ. Erasure of the paternal transcription program during spermiogenesis: the first step in the reprogramming of sperm chromatin for zygotic development. Dev Dyn. 2008;237:14631476. Erratum in: Dev Dyn. 2008;237:2279-2281.

59. Detich N, Bovenzi V, Szyf M. Valproate induces replication-independent active demethylation. J Biol Chem. 2003;278:27586-27592.

60. Sinclair KD, Allegrucci C, Singh R, Gardner DS, Sebastian S, Bispham J, Thurston A, Huntley JF, Rees WD, Maloney CA, Lea RG, Craigon J, McEvoy TG, Young LE. DNA methylation, insulin resistance, and blood pressure in offspring determined by maternal periconceptional B vitamin and methionine status. Proc Natl Acad Sci U S A. 2007;104:19351-19356.

61. Schaefer CB, Ooi SK, Bestor TH, Bourc'his D. Epigenetic decisions in mammalian germ cells. Science. 2007;316:398-399.

62. Morgan HD, Sutherland HG, Martin DI, Whitelaw E. Epigenetic inheritance at the agouti locus in the mouse. Nat Genet. 1999;23:314-318. 
63. Day JK, Bauer AM, DesBordes C, Zhuang Y, Kim BE, Newton LG, Nehra V, Forsee KM, MacDonald RS, Besch-Williford C, Huang TH, Lubahn DB. Genistein alters methylation patterns in mice. J Nutr. 2002;132(8 Suppl):2419S-2423S.

64. Bruniquel D, Schwartz RH. Selective, stable demethylation of the interleukin-2 gene enhances transcription by an active process. Nat Immunol. 2003;4:235-240.

65. Szyf M. The dynamic epigenome and its implications in toxicology. Toxicol Sci. 2007;100:7-23.

66. Mackay DJ, Boonen SE, Clayton-Smith J, Goodship J, Hahnemann JM, Kant SG, Njølstad PR, Robin NH, Robinson DO, Siebert R, Shield JP, White HE, Temple IK. A maternal hypomethylation syndrome presenting as transient neonatal diabetes mellitus. Hum Genet. 2006;120:262-269.

67. Mackay DJ, Callaway JL, Marks SM, White HE, Acerini CL, Boonen SE, Dayanikli P, Firth HV, Goodship JA, Haemers AP, Hahnemann JM, Kordonouri O, Masoud AF, Oestergaard E, Storr J, Ellard S, Hattersley AT, Robinson DO, Temple IK. Hypomethylation of multiple imprinted loci in individuals with transient neonatal diabetes is associated with mutations in ZFP57. Nat Genet. 2008;40:949-951.

68. Barker DJ, Eriksson JG, Forsén T, Osmond C. Fetal origins of adult disease: strength of effects and biological basis. Int J Epidemiol. 2002;31:1235-1239.

69. Huang WW, Yin Y, Bi Q, Chiang TC, Garner N, Vuoristo J, McLachlan JA, Ma L. Developmental diethylstilbestrol exposure alters genetic pathways of uterine cytodifferentiation. Mol Endocrinol. 2005;19:669-682.

70. Brouwers MM, Feitz WF, Roelofs LA, Kiemeney LA, de Gier RP, Roeleveld N. Hypospadias: a transgenerational effect of diethylstilbestrol? Hum Reprod.2006;21: 666-669.

71. Troisi R, Hatch EE, Titus-Ernstoff L, Hyer M, Palmer JR, Robboy SJ, Strohsnitter WC, Kaufman R, Herbst AL, Hoover RN. Cancer risk in women prenatally exposed to diethylstilbestrol. Int J Cancer. 2007;121:356-360.

72. Palmer JR, Wise LA, Hatch EE, Troisi R, Titus-Ernstoff L, Strohsnitter W, Kaufman R, Herbst AL, Noller KL, Hyer M, Hoover RN. Prenatal diethylstilbestrol exposure and risk of breast cancer. Cancer Epidemiol Biomarkers Prev.2006;15:1509-1514.

73. Newbold RR, Padilla-Banks E, Jefferson WN. Adverse effects of the model environmental estrogen diethylstilbestrol are transmitted to subsequent generations. Endocrinology. 2006;147(6 Suppl):S11-17.

74. Block K, Kardana A, Igarashi P, Taylor HS. In utero diethylstilbestrol (DES) exposure alters Hox gene expression in the developing müllerian system. FASEB $J$. 2000;14:1101-1108.

75. Eun Kwon H, Taylor HS. The role of HOX genes in human implantation. Ann N Y Acad Sci. 2004;1034:1-18. 
76. Akbas GE, Song J, Taylor HS. A HOXA10 estrogen response element (ERE) is differentially regulated by 17 beta-estradiol and diethylstilbestrol (DES). J Mol Biol. 2004;340:1013-1023.

77. Nilsson EE, Anway MD, Stanfield J, Skinner MK. Transgenerational epigenetic effects of the endocrine disruptor vinclozolin on pregnancies and female adult onset disease. Reproduction. 2008;135:713-721.

78. Anway MD, Skinner MK. Epigenetic programming of the germ line: effects of endocrine disruptors on the development of transgenerational disease. Reprod Biomed Online. 2008;16:23-25.

79. Vine MF, Setzer RW Jr, Everson RB, Wyrobek AJ. Human sperm morphometry and smoking, caffeine, and alcohol consumption. Reprod Toxicol. 1997;11:179-84.

80. Frazier LM. Reproductive disorders associated with pesticide exposure. $J$ Agromedicine. 2007;12:27-37.

81. Skinner MK, Anway MD. Seminiferous cord formation and germ-cell programming: epigenetic transgenerational actions of endocrine disruptors. Ann $N$ Y Acad Sci. 2005;1061:18-32.

82. Gurvich N, Berman MG, Wittner BS, Gentleman RC, Klein PS, Green JB. Association of valproate-induced teratogenesis with histone deacetylase inhibition in vivo. FASEB J. 2005;19:1166-1168.

83. Menegola E, Di Renzo F, Broccia ML, Giavini E. Inhibition of histone deacetylase as a new mechanism of teratogenesis. Birth Defects Res C Embryo Today. 2006;78:345-353.

84. Milutinovic S, D'Alessio AC, Detich N, Szyf M. Valproate induces widespread epigenetic reprogramming which involves demethylation of specific genes. Carcinogenesis. 2007;28:560-571.

85. Hunt S, Russell A, Smithson WH, Parsons L, Robertson I, Waddell R, Irwin B, Morrison PJ, Morrow J, Craig J; UK Epilepsy and Pregnancy Register. Topiramate in pregnancy: preliminary experience from the UK Epilepsy and Pregnancy Register. Neurology. 2008;71:272-276.

86. Martínez-Frías ML. Topiramate in pregnancy: Preliminary experience from the UK epilepsy and pregnancy register. Neurology. 2009;72:2054-2055.

87. Zhang B, Huang T, Liu K, Chen J, Wang G. Effects of 5-Aza-CdR on cell proliferation of breast cancer cell line MDA-MB-435S and expression of maspin gene. J Huazhong Univ Sci Technolog Med Sci. 2007;27:543-246.

88. Balada E, Ordi-Ros J, Serrano-Acedo S, Martinez-Lostao L, Vilardell-Tarrés M. Transcript overexpression of the MBD2 and MBD4 genes in CD4+ T cells from systemic lupus erythematosus patients. J Leukoc Biol. 2007; 81:1609-1616.

89. Cornacchia E, Golbus J, Maybaum J, Strahler J, Hanash S, Richardson B. Hydralazine and procainamide inhibit $\mathrm{T}$ cell DNA methylation and induce autoreactivity. $J$ Immunol. 1988;140:2197-2200. 
90. Simmons RA. Developmental origins of diabetes: the role of epigenetic mechanisms. Curr Opin Endocrinol Diabetes Obes. 2007;14:13-16.

91. Fraga MF, Ballestar E, Paz MF, Ropero S, Setien F, Ballestar ML, Heine-Suñer D, Cigudosa JC, Urioste M, Benitez J, Boix-Chornet M, Sanchez-Aguilera A, Ling C, Carlsson E, Poulsen P, Vaag A, Stephan Z, Spector TD, Wu YZ, Plass C, Esteller M. Epigenetic differences arise during the lifetime of monozygotic twins. Proc Natl Acad Sci U S A. 2005;102:10604-10609.

92. Heijmans BT, Tobi EW, Stein AD, Putter H, Blauw GJ, Susser ES, Slagboom PE, Lumey LH. Persistent epigenetic differences associated with prenatal exposure to famine in humans. Proc Natl Acad Sci U S A. 2008;105:17046-17049.

93. Painter RC, Osmond C, Gluckman P, Hanson M, Phillips DI, Roseboom TJ. Transgenerational effects of prenatal exposure to the Dutch famine on neonatal adiposity and health in later life. BJOG. 2008;115:1243-4129.

94. Lam PK, Torfs CP. Interaction between maternal smoking and malnutrition in infant risk of gastroschisis. Birth Defects Res A Clin Mol Teratol. 2006;76:182-186.

95. Rossignol S, Steunou V, Chalas C, Kerjean A, Rigolet M, Viegas-Pequignot E, Jouannet P, Le Bouc Y, Gicquel C. The epigenetic imprinting defect of patients with Beckwith-Wiedemann syndrome born after assisted reproductive technology is not restricted to the 11p15 region. J Med Genet. 2006;43:902-907.

96. Kagami M, Nagai T, Fukami M, Yamazawa K, Ogata T.Silver-Russell syndrome in a girl born after in vitro fecundation: partial hypermethylation at the differentially methylated region of PEG1/MEST. J Assist Reprod Genet. 2007;24:131-136.

97. Kurihara Y, Kawamura Y, Uchijima Y, Amamo T, Kobayashi H, Asano T, Kurihara H. Maintenance of genomic methylation patterns during preimplantation development requires the somatic form of DNA methyltransferase 1. Dev Biol. 2008;313:335-346.

98. Weksberg R, Shuman C, Caluseriu O, Smith AC, Fei YL, Nishikawa J, Stockley TL, Best L, Chitayat D, Olney A, Ives E, Schneider A, Bestor TH, Li M, Sadowski P, Squire J. Discordant KCNQ1OT1 imprinting in sets of monozygotic twins discordant for Beckwith-Wiedemann syndrome. Hum Mol Genet. 2002;11:1317-1325.

99. Oakes CC, La Salle S, Smiraglia DJ, Robaire B, Trasler JM.A unique configuration of genome-wide DNA methylation patterns in the testis. Proc Natl Acad Sci USA. 2007; 104:228-233. 
Figure 1. Paternal imprinting. Only the maternal allele is expressed.

Figure 2. Male and female gamete formation. Differences according to gender and certain epigenetic processes.

Figure 3: Modified from: Plusa et al. (2002) [38] and Zernicka-Goetz (2006)[41]

A. (1) Upon fecundation the maternal oocyte completes meiosis II. The whole paternal genome undergoes DNA demethylation, except for the paternally imprinted genes, centromeres, heterochromatin and some repetitive elements. (2) Once the two pronuclei are formed, they approximate to form the zygote. (3) The zygote anchors the second polar body (PB-II) to mark the animal pole, while the vegetal pole is established at the diametrically opposite side.

B. (1) The animal pole determines the plane of the first mitotic cleavage division in the zygote. (a) indicates the microtubules extending from the spindle poles anchored near the PB-II. (2) The first two blastomeres result from a meridian division. (3) Afterwards, at the blastocyst stage the embryonic-abembryonic axis will be established from these first two blastomeres (the colours are related (see text).

C. Detailed representation of development from the (1) 8-cell morula onwards. (2) At the 16-32 cell stage, two types of divisions occur: asymmetric and symmetric, and subsequently (3) cavitation takes place to generate (4) the blastocyst. Black lines indicate symmetric division, giving two external sister cells. Grey lines indicate symmetric division of internal cells. White lines indicate asymmetric division giving one external and another internal sister cell. $\mathrm{ZP}=$ zone pellucida. $\mathrm{TF}=$ trophectoderm. $\mathrm{TEP}=$ trophectoderm polar. $\mathrm{TEM}=$ trophectoderm mural. The coloured cells are related. 


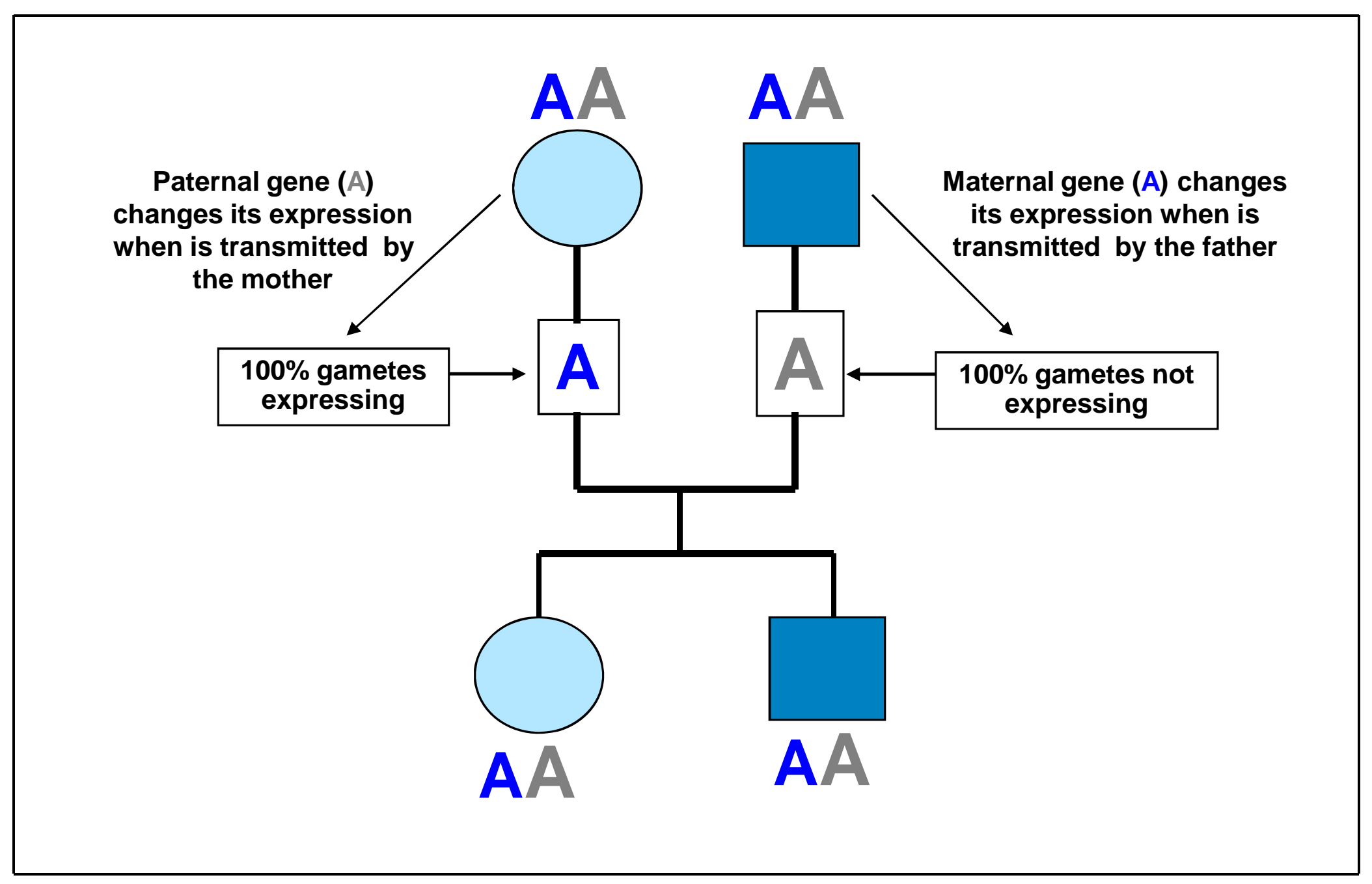

Figure 1. Paternal imprinting. Only the maternal allele is expressed. 


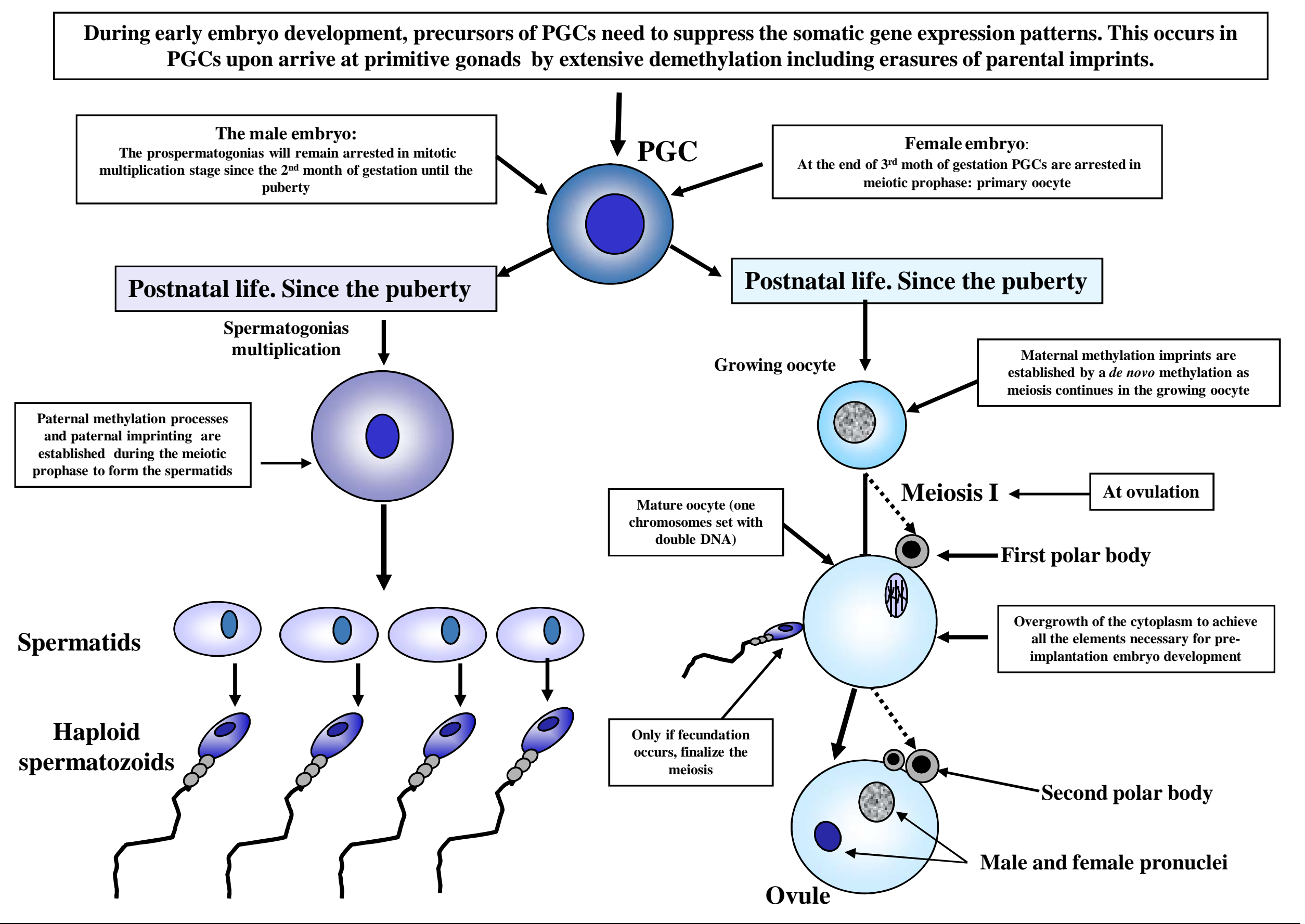

Figure 2. Gametes formation. Differences by sex, and occurrence of some epigenetic processes 

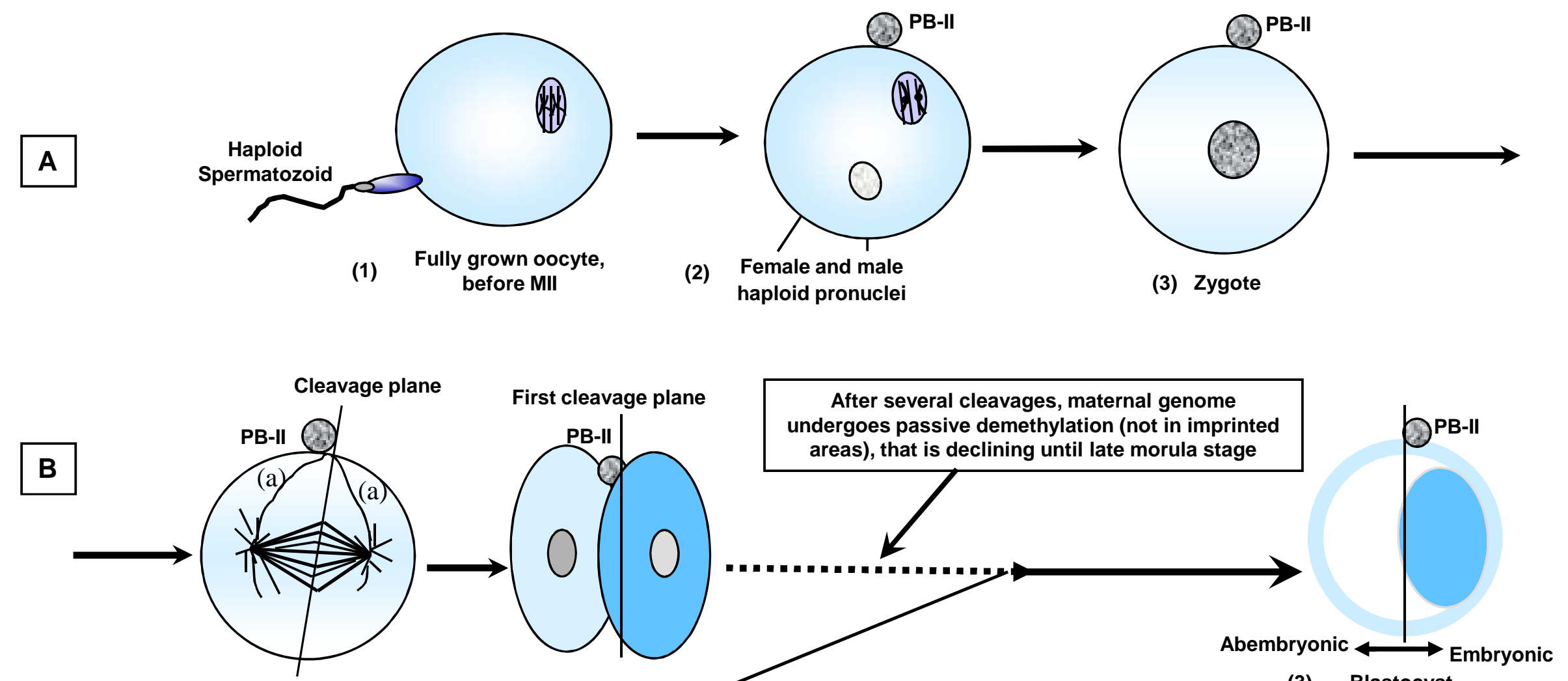

$\begin{array}{ll}\text { (1) First mitotic division } & \text { (2) 2-cell embryo }\end{array}$

(3) Blastocyst

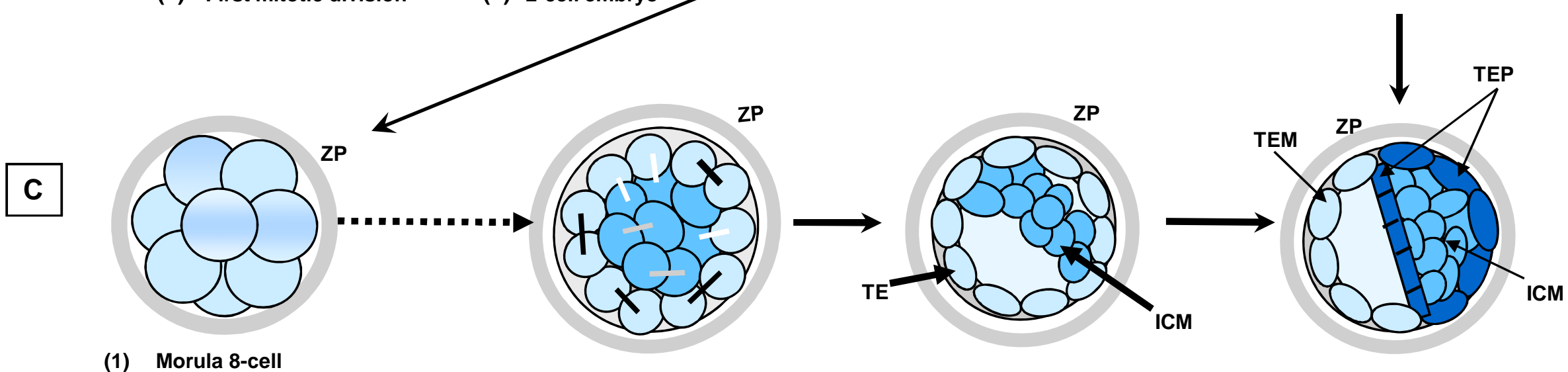

(1) Morula 8-cell

(2) 16-32 cell

(3) Cavitation

(4) Blastocyst

Figure 3 